\title{
Spiritual Values and Motives of Secular Pilgrims
}

\section{Abstract}

This study presents and tests an empirical model of the antecedents and outcomes associated with secular pilgrimage from a consumer perspective. Informed by the literature on spiritual journeys, religious and secular pilgrimage, consumer literature on personal values, emotions, customer satisfaction and recommendation behaviour, the study proposes that personal values of pilgrims positively affect their motives to partake in the spiritual journey of a secular pilgrimage. Pilgrimage motives positively affect pilgrim satisfaction directly, as well as indirectly through emotions associated with the spiritual pilgrimage experience. Pilgrim satisfaction is also positively affected by attributes of the pilgrimage site and results in an intention to recommend to family, friends, and others. The model was tested on a paired sample of visitors attending the pilgrimage site of Gallipoli in Turkey for the annual commemoration of the Australia and New Zealand Army Corps (Anzac) Day. The study results show statistical support for all hypothesized relationships in the theoretical model. Findings of this study contribute an improved understanding of the role of consumer values, motivations and emotions to undertake spiritual journeys to pilgrimage sites, and their satisfaction with the spiritual experience of a secular pilgrimage and the resultant recommending behaviour.

\section{Keywords}

Consumer, spirituality, pilgrim, values, motives, pilgrimage tourism, Gallipoli, battlefield 


\section{Introduction}

Pilgrimage has generally been associated with spiritual journeys to designated holy places such as shrines, for the primary purpose of participating in religious rituals. Each year, approximately 300 million people make pilgrimages to sacred sites (Abad-Galzacorta et al. 2016) to satisfy a variety of motives (Canoves \& Forga 2016). While it may be thought that the characteristics of these sites define them as sacred, it is the regular presence and behaviour of pilgrims that maintains and enlivens their sacredness (Bell 2009). There is, therefore an intimate relationship between pilgrimage, pilgrims, a sacred place and a spiritual experience.

In the past, only those travellers who undertook a spiritual journey to religious sites were categorised as pilgrims. However, current research shows that the defining feature of pilgrimage is not just religion, but may be dependent upon a variety of other motivational factors that influence pilgrims to visit a particular site (Buzinde et al. 2014). In an increasingly secular world, many consumers seek out meaning, self-awareness, and identity through spiritual experiences at different non-religious sites, thus blurring the distinction between religious versus non-religious pilgrimage or secular journeys (Bond, Packer \& Ballantyne 2015; Collins-Kreiner 2016).

Examples of religious pilgrimage include visitation to the Wailing Wall of Jerusalem for those of the Jewish faith, and visiting Mecca for Muslims. For many people today however, the fragmentation of religions globally and the complexities of modern life have given rise to the sacralisation of various non-religious places and events (Toohey \& Taylor 2013; Kim \& Butler 2015). Examples of secular pilgrimages include travel to Lords for the Ashes cricket test; Graceland to pay homage to Elvis Presley; and the Grand Ol’ Opre in Nashville (Gammon 2014; 
Crawford 2015; Edles 2016). Visits to battlefields like Waterloo, Gettysburg and the Western Front have also been portrayed as pilgrimages (Dunkley et al. 2011).

Literature on religious pilgrimage addresses satisfaction with amenities (Malodia \& Singla 2017), satisfaction and loyalty (Eid 2015). The motives of both religious and non-religious tourists to attend religious sites has also been researched (Abad-Galzacorta et al. 2016; Battour et al. 2017; Canoves \& Forga 2016; Choe, Blazey \& Mitas 2015; Lois-González \& Santos 2015), although the motives for secular visits have been less studied (Brown 2016; Hyde \& Harman 2011). Additionally, much of this work is qualitative in nature, and thus it is not designed " to provide information about broad-scale visitation trends” (Winter 2011, p. 165).

We adopt Hyde and Harman's (2011) definition of pilgrimage tourism as “travel to, and communion with, a specific, nonsubstitutable physical site that embodies and makes manifest the religious, cultural or personal values of the individual, the deeply meaningful, or a source of core identity for the traveller" (p. 1344), and address their call for future research to investigate the influence of traveller motives and personal values in respect of secular pilgrimage visits. In addition, we also address the call to further investigate the direct association of pilgrimage with consumption and marketing decisions, motivations and behaviour (Getz \& Page 2016).

The increasing volume of secular journeys across the globe represent an emerging form of travel behaviour worthy of investigation from a marketing and consumer perspective. In this paper, we integrate concepts found in past studies to facilitate a more comprehensive understanding of factors that affect pilgrims' satisfaction with a secular pilgrimage site. Based on existing research, 
we present and test a model that includes the antecedents (personal values, pilgrimage motives and emotions) and outcomes (pilgrim satisfaction and recommendation behaviour) of visitor attendance.

This study focuses on travel by Australians to the Gallipoli peninsula in Turkey for the annual Anzac Day commemorative ceremony held on the day of the landings (25th April). Gallipoli is the battlefield of a 9-month First World War campaign which began on the 25th April of 1915, when Australian and New Zealand (Anzac) forces landed on the beach and engaged the Turkish army. The campaign was an epic disaster for the British and their allies, with a total death toll of 25,000 Australians alone. For Turkey, Gallipoli was a costly victory, which exacted a death toll of 250,000 casualties including over 100,000 deaths. For many reasons that have been analysed elsewhere (see for example, Slade, 2003 and Lockstone-Binney et al. 2013), Gallipoli has come to be regarded as the birth place for the newly formed nations of Australia, New Zealand and Turkey, and as such, the battlefield is perceived by many as a sacred site of respective national importance for these countries.

Gallipoli has thus become a place of pilgrimage for Australians, which holds such wide support that Bouma (1992 p. 5) argues, “The Anzac legend and its remembrance is a sacred meaning system in Australian culture. No criticism is allowed”, while Scates (2006) refers to the pilgrimage as a rite of passage, particularly for young Australians. For visitors, a journey to Gallipoli on Anzac Day can be classified as a spiritual pilgrimage, which describes a way of marking generational links and continuity through their families as well as being personal quests for casting and re-creating of self and national identities in a global era (Hannaford 2001). 
The remainder of this paper is structured as follows. In the next section, we briefly discuss the notion of secular pilgrimage, followed by a presentation of the theoretical model. We then describe the research method consisting of a two-step quantitative survey. This is followed by the research findings and discussion of theoretical implications.

\section{Battlefield visitation as secular pilgrimage}

Pilgrimage as a religious undertaking shares many features with non-religious or secular pilgrimage, and contemporary research indicates that there is much blurring and overlap between them (Digance 2003). As noted earlier, pilgrimage, both religious and secular, involves a spiritual journey to a particular site at which a 'pilgrim' engages in ritualistic behaviours that are socially shared, and as such, they create the site as a sacred place (Bell 2009). The pilgrim's journey is further defined as that which presents a challenge in some way, such as being arduous, lengthy or involving access to a remote location (Eliade 1969). While pilgrimage is essentially a personal undertaking, groups of like-minded travellers may also experience a sense of communitas (Turner \& Turner 1978) along the way. Commemoration at large monuments often reflect a strong nationalistic sentiment as well as remembrance for the dead, thus spiritually linking pilgrims and tourists (Slade 2003). Importantly, pilgrims are thought to enter a liminal world, beyond the borders of their daily life, where they have the opportunity for extraordinary spiritual experiences, from which the pilgrim emerges, renewed and perhaps transformed (Eliade 1969; Hyde \& Harman 2011; Morinis 1984; Turner \& Turner 1978).

Lloyd (1998) explains that during the First World War, the battlefields were perceived as 
sacred because of the mass death that had occurred, and that "wartime imagery stressed the spiritual nature of the struggle. During the war soldiers were portrayed as heroes sacrificing themselves for their country; a sacrifice which was likened to that of Jesus Christ” (Lloyd 1998, p. 26). Today, visits to battlefields such as Gettysburg and Gallipoli continue to be viewed as secular pilgrimages that can invoke deeply emotional and spiritual experiences (Dunkley at el. 2011; Hannaford 2001; Hyde \& Harman 2011; Lockstone-Binney et al. 2013; Scates 2006). In a recent study of battlefields in England, Miles (2014, p. 144) found some evidence of spirituality which he refers to as "a deeper awareness of the events and an intangible sense of place" and "where people feel a sense of spiritual awe.” Seaton (1999, p. 140) in examining the 'sacrilization’ of the Waterloo battlefield in Belgium noted it is a "quasi-holy object in the eyes of the pilgrimtourist”.

Collectively, these studies support that pilgrims to battlefield sites can engage in a form of secular pilgrimage, the spiritual experiences and effects of which are not dissimilar to those partaking of a religious journey.

\section{Theoretical background}

The theoretical model of the antecedents and outcomes of secular pilgrimage attendance, as presented in Figure 1, proposes that personal values form the basis of pilgrimage motives to attend a pilgrimage site, which may evoke a range of spiritual experiences and emotions, which may lead to satisfaction with the pilgrimage experience and recommending behaviour may result.

\section{INSERT FIGURE 1}




\section{Personal Values}

Personal values have been defined as abstract beliefs about behaviours or end-states of existence that transcend specific situations and guide the selection or evaluation of behaviour and events (Eagly \& Chaiken 2007; Rokeach 1973; Schwartz \& Bilsky 1987). Personal values are a type of social cognition that reflects internal states that intervene between stimuli and responses and affect those responses (Kahle 1983).

Personal values help explain the causes of social behaviour across time and situations (Lönnqvist et al. 2013), and assist individuals to form attitudes, make judgments and comparisons, and guide the behaviour in which people choose to engage (Long \& Shiffman 2000; Rokeach 1973, 1979). Therefore, personal values may influence people’s motives for attendance to pilgrimage sites (Dunkley at el. 2011; Liutikas 2017), and consumer satisfaction (Paul, Sankaranarayanan \& Mekoth 2016). In a recent qualitative study using time diaries, Liutikas (2017) identified links between personal values and motives for pilgrimage and supported the spiritual and transformative power of such travel.

\section{Motives for secular pilgrimage}

Literature on religious tourism has highlighted the importance of understanding traveller motivations, and how these motivations affect journey satisfaction (Battour et al., 2017). The motives for visiting secular pilgrimage sites may vary from curiosity, to a search for meaning, and may also include a desire for personal growth, empathy, spiritual travel, and the quest for a strong sense of unity and involvement (Collins-Kreiner 2016). There have been a variety of reasons 
proffered as to why people desire to visit battlefields, some of which involve the notion of pilgrimage, and others, arguably, that do not. Despite having considerably different motives and engaging in different activities whilst at the pilgrimage sites (Winter 2009), visitors from distinct market segments may visit the same sites and coexist (Collins-Kreiner 2016). O’Bannon (2006) contends that most tourists who visit battlefields are interested in seeing history 'made real', while others attempt to recreate the drama of the event within the actual physical surroundings (Slade 2003). Commemoration of war and involvement in acts of remembrance remain one of the most important aspects of battlefield visitation (Scates 2006). Many visitors also wish to pay their respects to the dead, and to express their thoughts and gratitude towards them (Hyde \& Harman 2011; Winter 2015). For some, "the act of commemoration - the personal and collective remembrance - is driven by a moral obligation” (Dunkley et al. 2011, p. 867). Slade’s (2003) study of visitors to Gallipoli emphasized their desire to express a sense of nationality and to see the place at which their nation had been formed, findings supported by Lockstone-Binney et al. (2013).

\section{Emotions}

Emotions play a powerful, central role in people’s lives. Emotions impact beliefs, inform decision-making and extensively guide how people adapt behaviour to the world (Burns \& Neisner 2006). Emotions are viewed as intentional, and based on specific objects or referents. Consequently, emotions are not merely reactions to appraisals, but also include tendencies that initiate action (Frijda 1993). While apparent in moments of great stress, emotions sway even the most mundane of decisions faced in everyday life.

Research has supported the association between positive emotions and satisfaction with a 
consumer experience (Bigné, Andreu \& Gnoth 2005; Machleit \& Mantel 2001; Westbrook \& Oliver 1991). Similarly, research shows that strong emotional reactions are prevalent among visitors to battlefields (Chronis 2005; Dunkley et al. 2011). The emotional process dynamics are also characterised by the pilgrim in the cathartic spiritual experiences associated with pilgrimages (Cheer 2017, Lopez 2017). In a broader context, the role of emotions in affecting customer satisfaction has been supported (Ali, Amin \& Cobanoglu 2016), including a link between emotional satisfaction and subsequent behaviour (Jani \& Han 2013).

Satisfaction, Word-of-Mouth and Site Attributes

Consumer satisfaction can be regarded as an outcome of the post-purchase consumer experience, taking into account the costs and benefits outlaid (Yi 1990). According to Battour et al. (2017, p. 51), "the satisfaction level of (religious) tourists is significantly connected to the travel needs”. In terms of religious tourism, previous studies have indicated a link between the consequences of satisfaction, such as loyalty and retention (Eid 2015). Additionally, it has been determined that pilgrim's satisfaction is a function of destination amenities (Canoves \& Forga 2016), including factors such as transport, infrastructure, safety and facilities (Malodia \& Singla, 2017). Several tourism studies, have found a positive relationship between service evaluations of site attributes and overall satisfaction, with overall satisfaction acting as a predictor of future behavioural intentions including recommending behaviour (Hall et al. 2010; Kresic et al. 2013; Yuksel \& Rimmington 1998). In Hall et al.’s (2010) study of the attributes affecting satisfaction and visitor intentions in relation to the Gallipoli commemorative event, the ceremonies were unsurprising found to be the strongest element contributing to overall visitor satisfaction, with transport facilities to and around the site also prominently contributing. 
In summary, previous empirical work has studied a number of antecedents and outcomes of pilgrimage attendance. However, to our knowledge, no study has integrated values, motives, emotions, and site attributes within a model that links these with satisfaction and word-of-mouth intentions. It is important to understand the drivers of satisfaction as previous studies have shown that service dissatisfaction results in complaint behaviour (Donoghue \& Van Oordt 2016) and in this case, it is likely to reduce positive word-of-mouth and future pilgrimage travel.

\section{Research Method}

\section{Survey}

A two-step (pre- and post-trip) quantitative method was employed to gather information from Australian pilgrims to Gallipoli in 2009. Questionnaires were administered to bus travellers given this transport option is the most common way of reaching Gallipoli (Australian War Memorial 2009; Hall et al. 2010). We employed a cluster sampling approach (Malhotra, Hall, Shaw \& Oppenheim 2006), and chose one of the largest providers of bus transport services in Turkey, FEZ Travel, to provide a representative sample of Gallipoli pilgrims. This form of sampling is not uncommon in marketing and tourism research (Bosnjak \& Brand 2008; Bosnjak \& Rudolph 2008; Wang \& Davidson 2009). A two stage sampling process was utilized. From the 1,000 attendees using FEZ to travel to Gallipoli from Istanbul, 482 were interviewed and from this

process it was determined that only 331 would be returning directly back to Istanbul after the ceremony of which 190 responses were collected for this study, reflecting an effective response rate for the final paired sample of 57.4 per cent. 
Table 1 profiles the demographic characteristics of the 190 paired respondents, along with pre- and post-trip survey respondents. Both the pre- and post-trip samples are highly comparable with the final paired sample, indicating that the majority of pilgrim tourists were relatively young (18-30 years old), female, well-educated and employed individuals.

\section{INSERT TABLE 1 HERE}

For each construct contained in the theoretical model, an initial pool of items were collated based on existing literature (Churchill 1979). All items in the pool were pre-tested for comprehension, logic, and relevance over several iterations with five academics who had expertise in the areas of marketing and tourism. The final set of items were measured using an eleven-point semantic differential type scale (Juster 1964).

The pre-trip questionnaire included items directed at assessing personal values and pilgrimage motives. The personal values related to sense of belonging, sense of accomplishment, warm relationships, and self-fulfilment and were adapted from the well established List of Values (LOV) scale (Kahle et al. 1986). It is generally acknowledged that the LOV is designed to measure consumer values (McDaniel 2002), and because the subjects of this research were consumers at a pilgrimage site, Kahle's LOV was determined to be an appropriate value set to use for the purposes of the current study. Drawn from the extant literature, items related to motives for pilgrimage tourism assessed various reasons for visiting Gallipoli including the importance of attending a commemorative service, to reaffirm death not-in-vain, to show gratitude for freedom, to perform an act of remembrance and to affirm shared values, all of which highlight the integral spiritual 
nature of the pilgrimage experience (Inglis 2008; O’Bannon 2006; Ryan 2007; Scates 2006; Seaton 1996; Sharpley \& Stone 2009; Slade 2003).

The post-trip questionnaire included questions relating to various attributes of the Gallipoli pilgrimage site, including, waiting time in the queues, extent to which arrangements were made to control a large number of pilgrims, and the availability of toilet facilities. As the core program feature of the annual commemoration, pilgrim satisfaction was assessed relative to the two main ceremonies occurring at the site (the Dawn ceremony at Anzac Cove for both Australians and New Zealanders and the Lone Pine Cemetery ceremony that occurs later in the morning specifically for Australians), and perception of the appropriateness of the Dawn ceremony. These were developed with reference to Getz's (2000) conceptual framework, and those used by Chaplin and Costa (2000) in their exploratory analysis of a commemorative event. A further set of questions were incorporated post-trip to measure participants' emotions in relation to their Anzac Day visit to Gallipoli. The questions were adapted from Shaver et al.'s (1987) emotional typology, which has been used in several consumer behaviour studies relating emotions to customer satisfaction (Dunning, O’Cass \& Pecotich 2004, Lerner, Small \& Loewenstein 2004, Westbrook \& Oliver 1991), and covered the positively valanced emotion of love and negatively valanced emotion of sadness.

Finally, the participants' intent on recommending the pilgrimage visit to others upon their return to Australia was probed by questions that were adapted from previous research (Cronin, Brady \& Hult 2000; Getz 2008; Lee et al. 2007; Yi 1990; Yuksel \& Rimmington 1998). 


\section{Data analysis and Results}

Exploratory Factory Analysis (EFA) was employed to reduce the items into a smaller number of latent factors using principal axis factoring with varimax rotation. Only items that had loadings of 0.40 and above on a single factor were retained for further analysis. Following this, Confirmatory Factor Analysis (CFA) was run on each construct using guidelines suggested by Anderson and Gerbing (1988) to test the measures for convergent validity (coefficient alpha > 0.7) and internal consistency reliability (item-to-total correlations $>0.7$ ) in order to purify and refine the measurement scales for each construct.

Before estimating the path coefficients of the hypothesized relationships in the structural model, Confirmatory Factor Analysis (CFA) was used to fit a model using all the six latent factors, including the constructs of personal values, pilgrimage motives, emotions, site attributes, pilgrim satisfaction with ceremonies and recommendation.

The results of the CFA model are presented in Table 2. Fit indices indicated the model represented a good fit to the data (Hair, Babin, Anderson \& Tatham 2006; Kline 2005). All of the indices represented (see Table 2A) are within the acceptable range for the sample size. All the path coefficients between the indicators and their respective factors (latent constructs) were significant at $\alpha=0.01$ level (see Table 2B).

\section{INSERT TABLE 2}


Structural Equation Modelling (SEM) was subsequently used to test and analyse the relationships among these constructs. Figure 2 presents the resulting model of the antecedents and outcomes of the pilgrimage tourism visit to the Gallipoli battlefield site. The findings confirm the model relationships proposed in Figure 1.

\section{INSERT FIGURE 2}

The fit indices of the structural model also suggest a good fit to the data and all of the indices represented (see Table 3) are within the acceptable range for the sample size. $\mathrm{R}^{2}$ values for the construct of pilgrim satisfaction with ceremonies is 0.63 , which indicates a good amount of explained variance for a structural equation model.

\section{INSERT TABLE 3}

The empirical model showed several strong relationships between the constructs under study. There was a positive relationship between personal values and pilgrimage motives ( $\beta=$ 0.68, $\mathrm{p}<0.01)$, between pilgrimage tourism motives and emotions $(\beta=0.45, \mathrm{p}<0.01)$, between pilgrimage motives and pilgrim satisfaction with ceremonies $(\beta=0.34, \mathrm{p}<0.01)$, between emotions and pilgrim satisfaction with ceremonies $(\beta=0.52, \mathrm{p}<0.01)$, between site attributes and pilgrim satisfaction with ceremonies $(\beta=0.30, \mathrm{p}<0.01)$ and between pilgrim satisfaction with ceremonies and recommending behaviour $(\beta=0.49, \mathrm{p}<0.01)$. 


\section{Discussion and implications}

The study provides a comprehensive integrative model that identifies the respective importance of various antecedents to a secular pilgrimage visit and the resulting associated outcomes in terms of pilgrim satisfaction and recommending behaviour.

Addressing in part Hyde and Harman's (2011) call for research that investigates the importance of spiritual motives and values relative to the pilgrimage experience, the study supports that the pilgrimage visit, in this case to the Anzac Day ceremonies at the Gallipoli battlefield, is influenced by personal values, which strongly positively affect pilgrimage motives. The influencing values tested in the model included self fulfilment, sense of belonging, accomplishment and warm relations assessed using the LOV scale (Kahle et al., 1986). Results of our study lend empirical support to the proposed relationship between values, spirituality and pilgrimage noted in Kim et al.’s 2016 qualitative research and support the findings of Liutikas (2017, p. 223) who found that "conceptions of these values-based journeys could be described as pilgrimage, spiritual tourism”. 'Affirming shared values' was a strong indicator of the motives assessed, which supports the view that a sense of communitas (Turner \& Turner 1978) can be achieved whilst undertaking a pilgrimage experience.

The model suggests support for pilgrimage motives having an effect on emotions associated with the pilgrimage visit, which has an onward effect on pilgrim satisfaction, rather than motives directly affecting pilgrim satisfaction with ceremonies. These findings lend support to the view that travel to battlefields can be viewed as spiritual pilgrimages where deeply emotional experiences can be had (Hannaford 2001; Lockstone-Binney et al. 2013; Scates 2006; Winter 
2009). Given the Gallipoli campaign ended with 25,000 Australian casualties, a visit to Gallipoli may be regarded as a symbolic encounter with death that is associated with an intense emotional experience.

The link between the attributes of the pilgrimage site and pilgrim satisfaction with ceremonies was also supported. This is perhaps unsurprising given the facilitating role of these attributes. This role was conceptualised in an earlier model proposed by Crompton (2003) adapting Herzberg, Mausner and Snyderman's (1959) two-factor theory of job satisfaction to explore visitor satisfaction in a US festival setting. In the model, site maintenance attributes (weather, toilet facilities, parking facilities and information services) were conceptualized as acting like Herzberg's et al.'s hygiene factors, positive perception of which led to the avoidance of dissatisfaction outcomes. The event motivator attributes (e.g., entertainment, activities, features and educational programs) or satisfiers, were capable of promoting a positive visitor experience. Findings of this study reiterate the importance of site attributes in affecting pilgrim satisfaction with ceremonies, over and above that of pilgrim motives and emotions, which shape the spiritual experiential elements of the secular pilgrimage to Gallipoli on Anzac Day.

Confirming several previous studies (Hall et al. 2010; Kresic et al. 2013; Yuksel \& Rimmington 1998), the positive relationship between the satisfaction construct and intention to recommend the trip to others was confirmed.

Results of this study show empirical support for the postulated relationships initially proposed in Figure 1, by using a quantitative approach to study secular pilgrimage, and are 
complementary to the greater body of qualitative works in the area of spiritual and secular journeys (Winter 2009). Stemming from the study, potentially fruitful future research directions would overcome some of the limitations of this study including: 1) applying the model in other tourism contexts including religious visits to spiritual and/or religious events and sites 2) generalising the sample beyond tourists sourced by way of convenience methods 3) examining the relative antecedents and outcomes of visitation by pilgrims from the other key nations involved in the Gallipoli conflict 4) examining other antecedents, such as the level of religiosity of the pilgrim tourist, to assess the impact of new constructs relative to the others contained in the model.

Drawing management implications from the findings, Australian pilgrims visiting the Gallipoli battlefield in Turkey seek to manifest their values in respect of their travel motives. For organisers of the annual ceremonies held at this battlefield site and the associated travel industry facilitating attendance (tour operators, travel agents), it is imperative that they understand the various travel motives that influence pilgrims to visit the site, the most important of which is to affirm a sense of shared values amongst those visiting. Ensuring pilgrims are provided with opportunities in transit and on-site to coalesce in a respectful way is of the utmost importance, particularly in light of the strong emotions pilgrims experience when they come together at the site. Additionally, whilst not at the forefront of pilgrims minds and hearts, the underpinning importance of site attributes (toilets, crowd management onsite) supporting the core ceremonial elements of the Gallipoli commemorations cannot be ignored. Finally, satisfaction with those ceremonies is the key driver influencing positive word-of-mouth recommendations, ensuring that organisers should firmly keep the design and delivery of these ceremonial components central to their planning efforts and the travel sector market these to potential tourists. The broad findings of 
this study may also provide lessons for other pilgrimage sites.

\section{Conclusion}

This study furthers previous work on spiritual journeys and secular pilgrimage by presenting and empirically testing a conceptual model of the antecedents and outcomes of secular pilgrimage from a consumer perspective. This study integrates personal values, pilgrimage motives and emotions within a theoretical model, and links these to pilgrim satisfaction and recommendation behaviour related to a secular pilgrimage experience. Findings of this study give further insights into consumer behaviour related to a secular pilgrimage experience and contribute an improved understanding of the role of values, motives and emotions in the secular pilgrimage

experience. This study offers an explanatory model that can be supplemented with additional antecedent variables and replicated in other pilgrimage settings. 


\section{References}

Abad-Galzacorta M, Guereño-Omil B, Makua A, Iriberri JL, and Santomà R. (2016) Pilgrimage as tourism experience: The case of the Ignatian Way. International Journal of Religious Tourism and Pilgrimage 4(4): 48-66.

Ali F, Amin M and Cobanoglu C. (2016) An integrated model of service experience, emotions, satisfaction, and price acceptance: an empirical analysis in the Chinese hospitality industry. Journal of Hospitality Marketing \& Management 25(4): 449-475.

Anderson JC and Gerbing DW. (1988) Structural equation modelling practice: a review and recommended two-step approach. Psychological Bulletin 103 (3) 411-423.

Australian War Memorial [homepage on the internet] Australian War Memorial [Cited 2009 November 4]. Available from: http://www.awm.gov.au.

Battour M, Ismail MN, Battor M \& Awais M. (2017) Islamic tourism: an empirical examination of travel motivation and satisfaction in Malaysia. Current Issues in Tourism 20(1): 50-67.

Bell C. (2009) Ritual: Perspectives and dimensions. Oxford University Press: Oxford.

Bigné JE, Andreu L and Gnoth J. (2005) The theme park experience: An analysis of pleasure, arousal and satisfaction. Tourism Management 26(6): 833-844.

Bond N, Packer J and Ballantyne R. (2015) Exploring visitor experiences, activities and benefits at three religious tourism sites. International Journal of Tourism Research 17(5): 471-481.

Bosnjak M and Brand C. (2008) The impact of undesired self-image congruence on consumption-related attitudes and intentions. International Journal of Management 25(3): 673-683.

Bosnjak M and Rudolph N. (2008) Undesired self-image congruence in a low-involvement product context. European Journal of Marketing 42(5/6): 702-712. 
Bouma G. (1992) Religion: Meaning, transcendence and community in Australia. Longman Cheshire: Melbourne, Australia.

Brown L. (2016) Tourism and pilgrimage: Paying homage to literary heroes. International Journal of Tourism Research 18: 167-175.

Burns D and Neisner L. (2006) Customer satisfaction in a retail setting: The contribution of emotion. International Journal of Retail and Distribution Management 34(1): 46-66.

Buzinde CN, Kalavar JM, Kohli N amd Manuel-Navarrete D. (2014) Emic understandings of Kumbh Mela pilgrimage experiences. Annals of Tourism Research 49: 1-18.

Canoves G and Prat Forga JM. (2016) The determinants of tourist satisfaction in religious destinations: The case of Montserrat (Spain). International Journal of Religious Tourism and Pilgrimage 4(5): 26-36.

Chaplin I and Costa CMM. (2000) Milestone or millstone? Commemorating the Portuguese handover of Macau: Implications for event management. In Events beyond 2000: Setting the agenda. (ed. by J. Allen, R. Harris, L. K. Jago, \& A. J. Veal), pp. 212-221. Australian Centre for Event Management, University of Technology Sydney: Sydney, Australia.

Cheer J M, Belhassen, Y and Kujawa, J (2017) The search for spirituality in tourism: Toward a conceptual framework for spiritual tourism, Tourism Management Perspectives, 24:252-256

Choe J, Blazey M and Mitas O. (2015) Motivations of non-Buddhists visiting Buddhist temples. Current Issues in Tourism 18(1): 70-82.

Chronis A. (2005) Coconstructing heritage at the Gettysburg storyscape. Annals of Tourism Research 32(2): 386-406.

Churchill G. A., Jr. (1979) A Paradigm for Developing Better Measures of Marketing Constructs, Journal of Marketing Research 16 (1): 64-73 
Collins-Kreiner N. (2016) Dark tourism as/is pilgrimage. Current Issues in Tourism 19(12): 1185-1189.

Crawford, T. W. (2015). Finding the Real America on the TransAmerica Bicycle Trail: Landscapes and Meanings of a Contemporary Secular Pilgrimage. In The Changing World Religion Map (pp. 855-873). Springer Netherlands.

Crompton JL. (2003). Adapting Herzberg: a conceptualization of the effects of hygiene and motivator attributes on perceptions of event quality. Journal of Travel Research. 41: 305-310.

Cronin JJ Jr, Brady MK and Hult TM. (2000) Assessing the effects of quality, value, and customer satisfaction on consumer behavioural intentions in service environments. Journal of Retailing 76(2): 193-218.

Digance J. (2003) Pilgrimage at contested sites. Annals of Tourism Research 30: 143-159.

Donoghue S, Van Oordt C and Strydom N. (2016) Consumers' subjective and objective consumerism knowledge and subsequent complaint behaviour concerning consumer electronics: a South African perspective. International Journal of Consumer Studies 40(4): 385-399.

Dunkley R, Morgan N and Westwood S. (2011) Visiting the trenches: Exploring meanings and motivations in battlefield tourism. Tourism Management 32: 860-868.

Dunning J, O’ Cass A and Pecotich A. (2004) Retail sales explanations: Resolving unsatisfactory sales encounters. European Journal of Marketing 38(11/12): 151-161.

Eagly AH and Chaiken S. (2007) The advantages of an inclusive definition of attitude. Social Cognition 25: 582-602. 
Edles, L. D. (2016). International Voluntourism as Secular Pilgrimage: A Case Study of Hosts and Guests in a Small Panamanian Town. International Journal of Religious Tourism and Pilgrimage, 3(2), 5.

Eid R. (2015) Integrating Muslim customer perceived value, satisfaction, loyalty and retention in the tourism industry: An empirical study. International Journal of Tourism Research 17(3): 249-260.

Eliade M. (1969) The quest: History and meaning in religion. University of Chicago Press: Chicago, IL.

Frijda N. (1993) Moods, emotion episodes and emotions. In: Handbook of emotions (ed. by M. Lewis, \& J. M. Haviland-Jones), pp. 381-403. Guildford Press: New York, NY.

Gammon, S. (2014). Sport Events. Typologies, people and place. In The Routledge Handbook of Events (ed. by S. Page \& J. Connell) pp. 104-118. London Routledge.

Getz D. (2000) Developing a research agenda for the event management field. In Events beyond 2000: Setting the agenda. (ed. by J. Allen, R. Harris, L. K. Jago, \& A. J. Veal), pp. 9-20. Australian Centre for Event Management, University of Technology Sydney, Sydney, Australia.

Getz D. (2008) Event tourism: Definition, evolution, and research. Tourism Management 29: 403-428.

Getz D and Page SJ. (2016) Progress and prospects for event tourism research, Tourism Management 52: 593-631.

Hair JF, Babin B, Anderson RE and Tatham R. (2006) Multivariate data analysis, $6^{\text {th }}$ edn. Prentice-Hall: Upper Saddle River, NJ. 
Hall J, Basarin VJ and Lockstone-Binney L. (2010) An empirical analysis of attendance at a commemorative event: Anzac Day at Gallipoli. International Journal of Hospitality Management 29: 245-253.

Hannaford JA. (2001) Two Australian pilgrimages. [Unpublished Masters Thesis], Australian Catholic University, Melbourne, Australia.

Herzberg F., Mausner B and Snyderman B. (1959) The motivation to work. John Wiley: New York.

Hyde K and Harman S. (2011) Motives for a secular pilgrimage to the Gallipoli battlefields. Tourism Management 32(6): 1343-1351.

Inglis KS. (2008) Sacred Places: War Memorials in the Australian Landscape, $3^{\text {rd }}$ edn. Melbourne University Publishing, Carlton, Melbourne, Australia.

Izard CE. (1977) Human emotions. Plenum Press, New York, NY.

Jani D and Han H. (2013) Personality, social comparison, consumption emotions, satisfaction, and behavioral intentions: How do these and other factors relate in a hotel setting?. International Journal of Contemporary Hospitality Management 25(7): 970-993.

Juster FT. 1964 Anticipation and Purchases: An Analysis of Consumer Behaviour, National Bureau of Economic Research, Princeton, USA.

Kahle LR. (1983). Social values and social change: Adaptation to life in America. Praeger, New York, NY.

Kahle LR, Beatty SE and Homer P. (1986) Alternative measurement approaches to consumer values: The List of Values (LOV) and Values and Life Style (VALS). Journal of Consumer Research 13(3): 405-409. 
Kim, B, Kim, SS, and King, B (2016) The sacred and the profane: Identifying pilgrim traveler value orientations using means-end theory, Tourism Management, Volume 56: 142-155

Kim, S., \& Butler, G. (2015). Local community perspectives towards dark tourism development: The case of Snowtown, South Australia. Journal of Tourism and Cultural Change, 13(1), 7889.

Kline RB. (2005) Principles and practice of structural equation modelling, $2^{\text {nd }}$ edn. Guildford Press, New York, NY.

Kresić D, Mikulić J and Milicević K. (2013). The factor structure of tourist satisfaction at pilgrimage destinations: the Case of Medjugorje. International Journal of Tourism Research 15: $484-494$.

Lee SY, Petrick JF and Crompton J. (2007) The roles of quality and intermediary constructs in determining festival attendees’ behavioural intention. Journal of Travel Research 45(4): 402412.

Lerner J, Small DA and Loewenstein G. (2004) Heart strings and purse strings: Carryover effects of emotions on economic decisions. Psychological Science 15(5): 337-341.

Lloyd DW. (1998) Battlefield tourism: Pilgrimage and commemoration of the Great War in Britian, Australia and Canada, 1919-1939. Berg, Oxford, UK.

Liutikas D. (2017) The manifestation of values and identity in travelling: The social engagement of pilgrimage. Tourism Management Perspectives 24: 217-224.

Lockstone-Binney L, Hall J and Atay L. (2013) Exploring the conceptual boundaries of diaspora and battlefield tourism: Australians travel to the Gallipoli battlefield, Turkey, as a case study. Tourism Analysis 18: 297-311. 
Lois-González RC and Santos XM (2015). Tourists and pilgrims on their way to Santiago. Motives, Caminos and final destinations. Journal of Tourism and Cultural Change 13(2): $149-164$.

Long M and Schiffman L. (2000) Consumption values and relationships: Segmenting the market for frequency programs. Journal of Consumer Marketing 17(3): 214-232.

Lönnqvist J, Verkasalo M, Wichardt PC and Walkowitz G. (2013) Personal values and prosocial behaviour in strategic interactions: Distinguishing value-expressive from value-ambivalent behaviours. European Journal of Social Psychology 43(6): 554-569.

Lopez, Rubén Camilo Lois González, Belén Ma Castro Fernández (2017) Spiritual tourism on the way of Saint James the current situation, Tourism Management Perspectives, 24:225-234

Machleit KA and Mantel SP. (2001). Emotional response and shopping satisfaction moderating effects of shopper attributions Journal of Business Research 54(2): 97-106.

Malodia S and Singla H (2017). Using HOLSAT to evaluate satisfaction of religious tourist at sacred destinations: the case of religious travelers visiting sacred destinations in the Himalayas, India. International Journal of Culture, Tourism and Hospitality Research 11(2): 255-270.

Malhotra N, Hall J, Shaw M and Oppenheim P. (2006) Marketing research, $3^{\text {rd }}$ edn. Pearsons Education, French's Forest, NSW, Australia.

McDaniel S. (2002) An exploration of audience demographics, personal values and lifestyle: influence on viewing network coverage of the 1996 Summer Olympic Games, Journal of Sport Management 16: 117 -131.

Miles S. (2014) Battlefield sites as dark tourism attractions: an analysis of experience. Journal of Heritage Tourism 9 (2): 134-147. 
Moore A. (1980) Walt Disney World: Bounded ritual space and the playful pilgrimage centre. Anthropological Quarterly 53(4): 207-218.

Morinis EA. (1984) Pilgrimage in Hindu tradition: A case study of West Bengal. Delhi, India: Oxford University Press.

O’Bannon DT. (2006) Battlefield tourism. The dark tourism forum. University of Lancashire, Lancashire, UK.

Paul J, Sankaranarayanan KG and Mekoth N. (2016) Consumer satisfaction in retail stores: Theory and implications. International Journal of Consumer Studies 40(6): 635-642.

Rokeach M. (1973) The nature of human values. Free Press, New York, NY.

Rokeach M. (1979) Understanding human values: Individual and societal. Free Press, New York, NY.

Ryan C. (2007) Battlefield tourism: History, place and interpretation. Elsevier, Oxford, UK.

Scates B. (2006) Return to Gallipoli: Walking the battlefields of the Great War. Cambridge University Press, Cambridge, UK.

Schwartz S and Bilsky W. (1987) Toward a universal psychological structure of human values. Journal of Personality and Social Psychology 53(3): 550-562.

Seaton AV. (1996) From thantopsis to thanatourism: Guided by the dark. International Journal of Heritage Studies 2: 234-244.

Seaton AV. (1999) War and thanatourism: Waterloo 1815-1914. Annals of Tourism Research 26(1): 130-158.

Sharpley R and Stone P. (2009) The darker side of travel: The theory and practice of dark tourism. Channel View Publications, Bristol, UK. 
Shaver P, Schwartz J, Kirson D and O’Connor C. (1987) Emotion knowledge: Further exploration of a prototype approach. Journal of Personality and Social Psychology 52: 10611086.

Slade P. (2003) Gallipoli thanatourism: The meaning of Anzac. Annals of Tourism Research 30(4): 779-794.

Toohey, K., \& Taylor, T. (Eds.). (2013). Australian Sport: Antipodean Waves of Change. Routledge.

Turner V and Turner E. (1978) Image and pilgrimage in Christian culture. Columbia University Press: New York, NY:.

Wang Y and Davidson MCG. (2009) Chinese leisure tourists: perceptions and satisfaction with Australia, Tourism Analysis 14(6): 737-747.

Westbrook RA and Oliver RL. (1991) The dimensionality of consumption emotion patterns and consumer satisfaction. Journal of Consumer Research 18(1): 84-91.

Winter C. (2009) Tourism, social memory and the Great War. Annals of Tourism Research, 36(4): 607-626.

Winter C. (2011) Battlefield visitor motivations: Explorations in the Great War Town of Ieper, Belgium. International Journal of Tourism Research 13: 164-176.

Winter C. (2015) Ritual remembrance and war: Social memory at Tyne Cot. Annals of Tourism Research 54: 16-29.

Yi Y. (1990) A critical review of consumer satisfaction. In Review of Marketing (ed. by V. A. Zeithaml). American Marketing Association, Chicago, IL.

Yuksel A and Rimmington M. (1998) Customer-satisfaction measurement. Cornell Hotel and Restaurant Administration Quarterly 39(6): 60-70. 


\section{Tables and figures}

\section{Table 1}

Demographic Profile of Respondents

\section{Pre-trip Post-trip $\quad$ Paired}

Age

$\begin{array}{rlll}18-30 \text { years } & 77 \% & 73 \% & 71 \% \\ 30+\text { years } & 23 \% & 27 \% & 29 \%\end{array}$

Gender

$\begin{array}{rrrr}\text { Male } & 42 \% & 42 \% & 37 \% \\ \text { Female } & 58 \% & 58 \% & 63 \%\end{array}$

Education

$\begin{array}{rlll}\text { Primary/ Secondary } & 17 \% & 21 \% & 22 \% \\ \text { Tertiary } & 83 \% & 79 \% & 78 \%\end{array}$

Occupation

\begin{tabular}{rrrr} 
Managerial/Professional & $41 \%$ & $41 \%$ & $41 \%$ \\
Para-professional & $13 \%$ & $12 \%$ & $10 \%$ \\
Clerical/secretarial & $14 \%$ & $15 \%$ & $16 \%$ \\
Tradesperson & $14 \%$ & $16 \%$ & $14 \%$ \\
Sales or hospitality & $9 \%$ & $8 \%$ & $11 \%$ \\
Machine operator-driver & $1 \%$ & $1 \%$ & $1 \%$ \\
Labourer/Storesperson/Unskilled & $2 \%$ & $2 \%$ & $1 \%$ \\
Unemployed & $1 \%$ & $1 \%$ & $1 \%$ \\
Student & $4 \%$ & $3 \%$ & $4 \%$ \\
Retired & $1 \%$ & $1 \%$ & $1 \%$ \\
& & & $\mathrm{~N}=190$ \\
\hline
\end{tabular}


Table 2

A. Confirmatory Factor Model - Indices of Fit

\begin{tabular}{ccccccc} 
DF & $\mathrm{P}$ & CMIN/DF & GFI & CFI & IFI & RMSEA \\
\hline 174 & .00 & 1.33 & 0.90 & 0.96 & 0.96 & 0.04
\end{tabular}

B. Results of the CFA

\begin{tabular}{|l|l|c|c|c|c|}
\hline \multicolumn{1}{|c|}{ Indicator* } & \multicolumn{1}{|c|}{ Construct } & $\begin{array}{c}\text { Standardised } \\
\text { Loading }\end{array}$ & $\begin{array}{c}\text { Un-standardised } \\
\text { Loading }\end{array}$ & SE & t-value \\
\hline Warm Relationships & Personal Values & 0.60 & 1.00 & - & - \\
\hline Self-fulfilment & Personal Values & 0.80 & 1.25 & 0.16 & 8.03 \\
\hline Sense of Belonging & Personal Values & 0.80 & 1.28 & 0.16 & 8.03 \\
\hline Sense of Accomplishment & Personal Values & 0.73 & 1.31 & 0.17 & 7.58 \\
\hline Commemorative Ceremony & Pilgrimage Motives & 0.55 & 1.00 & - & - \\
\hline Re-affirm death not-in-vain & Pilgrimage Motives & 0.54 & 1.20 & 0.22 & 5.53 \\
\hline Gratitude for freedom & Pilgrimage Motives & 0.65 & 0.79 & 0.13 & 6.27 \\
\hline Act of remembrance & Pilgrimage Motives & 0.55 & 0.98 & 0.17 & 5.69 \\
\hline Affirm shared values & Pilgrimage Motives & 0.77 & 1.36 & 0.20 & 6.83 \\
\hline Love & Emotion & 0.36 & 1.06 & 0.25 & 4.17 \\
\hline Sadness & Emotion & 0.67 & 1.00 & - & - \\
\hline Gallipoli Experience & Emotion & 0.82 & 1.03 & 0.15 & 6.98 \\
\hline Anzac Ceremony & Pilgrim Satisfaction & 0.73 & 1.13 & 0.14 & 7.95 \\
\hline Lone Pine Ceremony & Pilgrim Satisfaction & 0.54 & 1.09 & 0.17 & 6.39 \\
\hline Dawn Ceremony & Pilgrim Satisfaction & 0.67 & 1.00 & - & - \\
\hline Crowd Control & Site attributes & 0.53 & 0.69 & 0.10 & 6.94 \\
\hline Toilets & Site attributes & 0.84 & 1.00 & - & - \\
\hline Queuing & Site attributes & 0.84 & 1.06 & 0.12 & 8.90 \\
\hline Family & Recommendation & 0.88 & 1.28 & 0.09 & 13.43 \\
\hline Friends & Recommendation & 0.91 & 1.00 & - & - \\
\hline Others & Recommendation & 0.61 & 0.57 & 0.06 & 9.04 \\
\hline
\end{tabular}

* All indicators are individual scale items included in the pre- and post trip questionnaires 
Table 3

Structural Equation Model - Indices of Fit

\begin{tabular}{ccccccc} 
DF & $\mathrm{P}$ & CMIN/DF & GFI & CFI & IFI & RMSEA \\
\hline 183 & .00 & 1.31 & 0.90 & 0.96 & 0.96 & 0.04
\end{tabular}


Figure 1

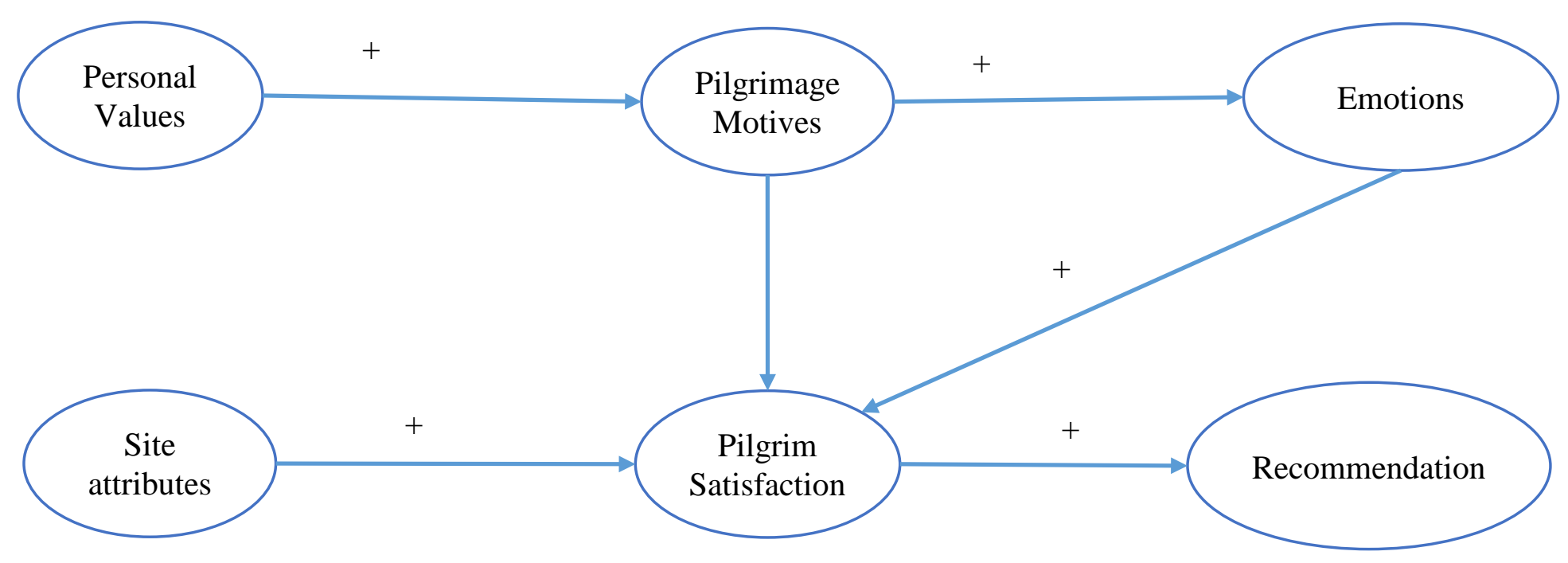

Figure 1: Theoretical Model of Antecedents and Consequences of Visitors’ Attendance at a Pilgrimage Event 


\section{Figure 2}

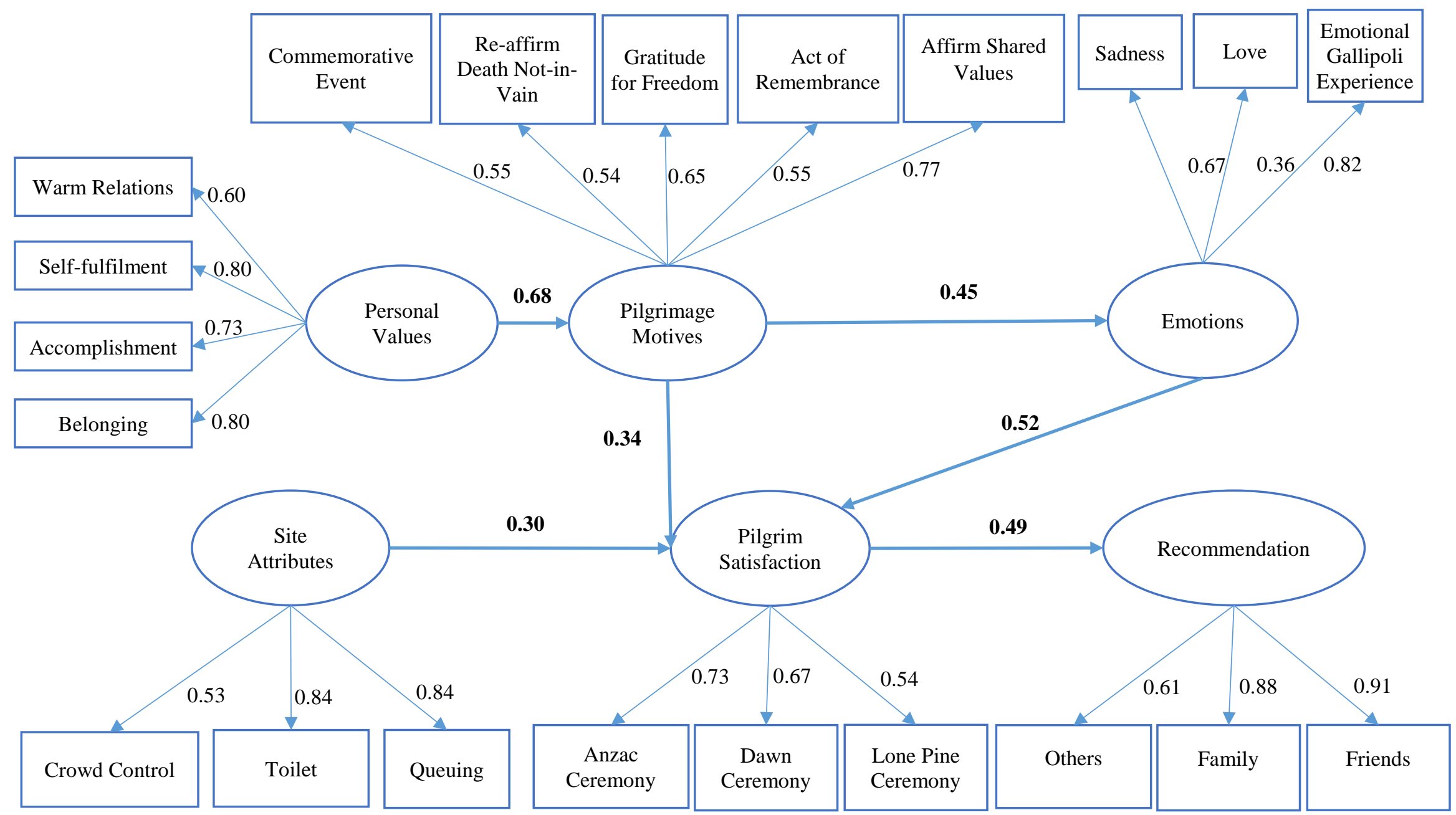

Figure 2: Structural Model of Antecedents and Consequences of Visitors’ Attendance at a Pilgrimage Site

Notes: All relationships between indicators (individual scale items) and their respective contructs are statistically significant ( $p<$ 0.01). All hypothesized relationships between constructs are statistically significant $(p<0.01)$. All values are standardized estimates. 